\title{
A Response to Anastasia Piliavsky's The Wrong Kind of Freedom? A Review of David Graeber's The Utopia of Rules: On Technology, Stupidity and the Secret Joys of Bureaucracy (Brooklyn/London: Melville House, 2015, 261 pages).
}

\section{David Graeber ${ }^{1}$}

Published online: 13 January 2017

(C) Springer Science+Business Media New York 2017

I've been asked to respond to the review of Utopia of Rules by Anastasia Piliavsky, but I must confess I find myself rather at a loss for how to do so.

The book is a collection of essays (I had originally wanted to call it "Three Essays on Bureaucracy") which I had hoped might spark a debate about what I call the present "age of total bureaucratization." In the introduction, I argue that since the 1970s, we have seen a kind of synthesis of public and private bureaucracies in a way that has made administrative procedures such a constant fixture of our everyday existence that we no longer even notice them, and that, what is more, the accompanying fusion of private and public power has become the main means of surplus extraction under capitalism. The essays set out to explore the cultural consequences of this new dispensation and its social, political, and even technological effects. I even propose a new general sociological principle, the "iron law of liberalism"- that is, that any market reform purportedly designed to cut red tape and reduce government interference in the economy will actually have the ultimate effect of increasing the total number of regulations, paperwork, and civil servants instead. The book is playful and whimsical in parts - jumping back and forth between analyses of Civic Republicanism or Pythagoreanism, Dungeons and Dragons, James Bond, and Batman - but it also makes a series of quite theoretical interventions (for instance, about the nature of violence, creativity, ideology, and the institutional constraints of academic life) that hope would spark fruitful debate.

The book the reviewer seems to have read is entirely different. It appears to be some sort of dogmatic anarchist tract which condemns all forms of bureaucracy, indeed, rule-governed behavior of any sort - in the name of a principle of absolute freedom founded on play and creative improvisation.

David Graeber

d.graeber@1se.ac.uk

1 London School of Economics and Political Science, London, UK 
On first reading the review, I was quite startled. Had I really written such a book? Was it possible I had gotten carried away with some strange passion, wrote a treatise condemning all forms of organization, and then, in a fit of absent-mindedness, simply forgotten I had done so? I was pretty sure I had not. In fact, I had thought that in writing the book, I had carefully avoided identifying myself as an anarchist or spelling out explicitly anarchist positions of any sort. Curious, I located a pdf on my hard drive and started word searching.

Mercifully, the results confirmed that I had not, in fact, been suffering from a lapse of memory. True, the word "anarchist" or "anarchism" did appear, between them, roughly fifteen times (somewhat more than I remembered), but not a single one of those fifteen appearances took the form of an explicit advocacy of anarchism. Most were purely descriptive (a third for instance referred to superheroes or supervillains being framed as or referred to as anarchists in Hollywood movies). The only ones that had an explicit bearing on anarchist attitudes towards bureaucracy were two mentions on page 158 of Kropotin's support for the bureaucratic structure of the post office as a possible model for a stateless society. Anyway, I was relieved to discover that, just as I had remembered it, no statement like "I am an anarchist," "smash the state!" or "much better to adopt the anarchist position" appear in the book anywhere at all.

Neither at any point in the book do I propose the systematic elimination of all forms of bureaucracy.

Now, it is certainly true that in certain sections, I identify myself with that anti-authoritarian tradition that wishes to replace bureaucratized forms of violence with bottom-up, directly democratic structures. But here, I am quite careful to note that ultimately, it is the violence, and not the bureaucratic procedures themselves, that I find objectionable. In fact, such passages (they are almost all to be found in the first essay) are more descriptive than prescriptive; I am describing a movement, though in a very sympathetic way, and anyway, I studiously avoid laying out any vision of what absolute success for such a movement might entail, let alone what degree of impersonal (i.e., bureaucratic) structures would need to be maintained if the movement is absolutely successful. This is partly because I see no particular reason why I should, partly because I don't believe such questions can be answered at this juncture anyway, and partly, too, because I believe that the idea that anyone should be laying down the law on such matters, rather than working to help create the democratic institutions, whereby people can decide for themselves how much bureaucracy they would like to have in their lives, is precisely the problem.

Insofar, as I weigh in on the question at all in the book, I make it clear that I do not believe that given the opportunity, people are likely to eliminate bureaucratic procedures entirely:

Bureaucracy holds out at least the possibility of dealing with other human beings in ways that do not demand either party has to engage in all those complex and exhausting forms of interpretive labor described in the first essay in this book, where just as you can simply place your money on the counter and not have to worry about what the cashier thinks of how you are dressed, you can also pull out your validated photo ID card without having to explain to the librarian why you are so keen to read about homoerotic themes in eighteenth century British verse. Surely, this is part of the appeal. In fact, if one really ponders the matter, it is hard to imagine how, even if we do achieve some utopian communal society, some impersonal (dare I say, bureaucratic?) institutions would not still be necessary, and for just this reason. To take one obvious example: languishing on some impersonal lottery system or waiting list for a desperately needed organ transplant might be alienating and distressing, but it is difficult to envision any less impersonal way of allocating a limited pool of hearts or kidneys that would not be immeasurably worse (p.152.) 
Similarly, in chapter 1, I note that bureaucratic procedures are not inherently stupid, but are rather ways of "managing social situations that are already stupid because they are founded on structural violence" (p.57). The obvious implication is that, absent the violence, such procedures would not necessarily be objectionable, and indeed I have argued precisely this on repeated occasions when actually talking about my vision of a stateless society, which I was very much not doing in this book.

I find it slightly puzzling that the reviewer does not acknowledge any of this. I thought I had made my position clear. But it happens again and again. Take for instance, the story about the DAN car. The idea that DAN having to give up its car reveals the unworkability of direct democracy is quite bizarre. The point of the story was that it is hard to maintain internal direct democracy in a group when one regularly has to deal with men with firearms saying "take me to your leader"- especially if they also have the power to lock you up if you do not comply. And having a car means having to deal with such armed men regularly. Once again, it is not a point about proceduralism. It is a point about violence.

So in this case, the reviewer's argument seems to come down to "it can be hard to maintain direct democracy within a society aggressively hostile to direct democracy, so therefore societies that are not aggressively hostile to direct democracy cannot exist." How does that make any sort of sense?

Finally, I guess I will have to address the reviewer's claim that as an advocate of free play and creativity I am opposed to all forms of rules and systematization of any kind. It seems a little silly that I should have to prove I am not a lunatic. But apparently I must.

So here goes. The reviewer asks: how would it be possible to organize, say, a train system in a society with no rules at all? My answer is it would not be possible to do so, and this is why it would never occur to me to advocate a society with no rules at all. Here again, I actually wrote a paragraph explaining why that was not my position (not that I should really have had to, since it is an absurd position that no one would actually hold, but as it happens I did write it):

It is worth thinking about language for a moment, because one thing it reveals, probably better than any other example, is that there is a basic paradox in our very idea of freedom. On the one hand, rules are by their nature constraining. Speech codes, rules of etiquette, and grammatical rules, all have the effect of limiting what we can and cannot say. It is not for nothing that we all have the picture of the schoolmarm rapping a child across the knuckles for some grammatical error as one of our primordial images of oppression. But at the same time, if there were no shared conventions of any kind - no semantics, syntax, and phonemics - we had all just be babbling incoherently and would not be able to communicate with each other at all. Obviously in such circumstances, none of us would be free to do much of anything. So at some point along the way, rulesas-constraining pass over into rules-as-enabling, even if it is impossible to say exactly where. Freedom, then, really is the tension of the free play of human creativity against the rules it is constantly generating (p.199).

Rather than claiming that freedom can only come by eliminating all rules, I explicitly say that without rules, freedom would be meaningless.

In case that was not clear enough:

Freedom has to be in tension with something, or it is just randomness. This suggests that the absolute pure form of play, one that really is absolutely untrammeled by rules of any sort (other than those it itself generates and can set aside at any instance) itself can exist 
only in our imagination, as an aspect of those divine powers that generate the cosmos... There is also something potentially terrifying about play for just this reason, because this open-ended creativity is also what allows it to be randomly destructive. Cats play with mice. Pulling the wings off flies is also a form of play. Playful gods are rarely ones any sane person would desire to encounter (p.192-93).

I could go on but I think I have made my point. Far from advocating absolute play, I argue that its prospect often inspires legitimate terror. Games, in contrast, are I argue pleasurable in part because they are on of the few situations in life where everyone actually knows exactly what the rules are (that is what the "utopia of rules" of the title refers to.) Freedom is the tension between the two.

In conclusion: not only are almost none of the actual arguments I make in the book addressed in this review but almost all of the positions the reviewer does attribute to me are anticipated and explicitly rejected in the text. One has to ask oneself, then: how could something like this have happened? It is not like the passages cited above are written in particularly obscure or difficult language. (at least I think they are not.) How could the reviewer have missed them? The only conclusion to which I can really come is that what happened was something like this.

The reviewer

1) Was aware of my political affiliation ("anarchist") from sources other than the book

2) Came up with a kind of fantasy version of what positions she imagined an anarchist would hold on bureaucracy, rules, etc.

3) Searched the book for material that would seem to confirm this fantasy position, ${ }^{1}$ ignoring all passages that directly contradicted it

4) Proceeded to write a review not of the book, but of the fantasy, drawing on occasional passages in the book as apparent illustration

This is really too bad because the book was meant to spark a conversation, first of all, within the society at large about paperwork, markets, the Internet, and related topics, second of all, within the left about what a broad left-wing critique of bureaucracy, to challenge the predominant right-wing critique of bureaucracy, might be like. Rather than addressing any of this or even really acknowledging it, the reviewer seems to take it for granted that right-wing intellectual hegemony is so absolute and unassailable that any public challenge to bureaucracy will only reinforce the right-wing narrative ("risk collusion with libertarians and the Right" are her exact words) - apparently, because replacing it with a left-wing narrative is deemed ipso facto impossible.

Since it would also be a shame to take up so many pages of an academic journal just to prove that there is scholar in the world who does not embrace absurdities, let me see if I cannot use this somewhat unfortunate exchange to make a broader point. It strikes me that the two approaches outlined here - the substitution of name-calling for debate and the political defeatism - are related. Insofar, as there is a dynamic element in the contemporary left, one that both envisions a future of genuine human liberation (however conceived) and is willing to take radical steps to achieve it, it is coming from the anti-authoritarian tradition that has

${ }^{1}$ Even if, in certain cases, they are quotes from other authors that are directly contradicted by other statements that I made myself. 
historically been identified with anarchism, though at this point, probably only a relatively small minority involved in that sort of politics would still wish to use the name. (I have myself been rather ambivalent in this regard: I wrote an essay once called "Fragments of an Anarchist anthropology" but only to argue that such a discipline did not exist; I have called myself an anarchist as a gesture of acknowledgement of intellectual ancestors, but have worked almost exclusively in activist groups that do not identify themselves as anarchist, even if they work on broadly anti-authoritarian principles - the Global Justice Movement, and Occupy, being only the two best known examples. I have explicitly stated on numerous occasions that there is no such thing as "anarchist anthropology" and I in no sense see myself as practicing it.) The insistence on treating anything written from a perspective broadly sympathetic with those direct democracy-oriented, anti-authoritarian movements as anarchist tracts putting forth selfevidently absurd positions (whatever their actual content), the ascription of emotional motives to the authors (I am for instance regularly referred to by reviewers as "hateful" or "angry" even in reference to tracts that are overtly whimsical and playful in tone), in the same way that accusations of "class hatred" or "man hating" was used to dismiss socialists and feminists of past generations, all this is, effectively, a way for academics to preserve their sense of themselves as left of centre while still insisting that any serious movement in the direction of greater freedom and democracy is quite impossible.

It certainly cannot be denied that the political label "anarchist" is deployed very differently than others. It would be inconceivable, for instance, to imagine an academic journal such as this reviewing a book on bureaucracy by a professor at a well-known university that begins by saying its author "loves bureaucracy with a Labour Party love" or "hates bureaucracy with a LibDem hatred." Indeed, it is generally speaking taboo to mention an author's political affiliations at all, unless, perhaps, they are an adherent of the National Front or something considered equally outré. Once, on twitter, I put out the question of whether there were any anthropologists who openly supported the Conservative party. Some anonymous tweeter popped up offering a couple names, and I responded that, if true, that would be interesting. Within hours, I was being denounced as "McCarthyite" for even asking the question. Yet, no one to my knowledge has ever accused anyone of McCarthyism for endlessly referring to me as "the anarchist anthropologist," despite the fact my twitter profile ends with the words "don't call me the anarchist anthropologist", 2 that I am widely rumored to have been kicked out of a job for being an anarchist (even I do not know if it is true or not because Yale refused to tell me the reasons for my dismissal), or that the British police have openly declared that just being identified as an anarchist is enough to merit one a police file as a potential subversive. ${ }^{3}$ One might have imagined that publicly identifying a scholar, against their will, as a left-wing subversive in a way that might get them in legal or professional difficulties might be

\footnotetext{
${ }^{2}$ Just to be clear, I do not object to being called an anarchist when it is actually relevant to my political theories or practice. But I do object to being called "the anarchist anthropologist" because (1) "anarchist" is not a type of anthropology, I do not practice "anarchist anthropology," in fact in Fragments, I argue that such a discipline does not exist; I'm simply a sociocultural anthropologist who happens to believe it would be possible and desirable to someday live without the state, and (2) since no Christian Democrat is ever called "the Christian Democratic anthropologist" or centrist Labour Party supporter a "the Blairite anthropologist", I would wish for consistent treatment in my own case as well.

${ }^{3}$ Another example: when New Left Review published a review of my book Debt: The First 500 Years by Robin Blackburn - the review itself was quite a favorable one - the editor decided to title it Anarchist Economics. The book does not mention anarchism once, and none of its arguments are in any sense derived from the anarchist tradition. It is actually a combination of Marxism and Post-Keynesianism.
} 
considered a form of McCarthyism, but that observing that they support the governing party would not. But apparently in contemporary academia, it is quite the other way around.

So clearly, once the word "anarchist" is invoked, different standards are held to applyespecially so, if there is any evidence that a scholar so labeled is not just putting it on for rhetorical effect, but might be inclined to apply anarchist principles in practice, even if only in very limited contexts to a very limited degree. Suddenly, ordinary standards of evidence seem to fall by the wayside. Rhetorical gestures that would be disallowed in polite society are now considered unobjectionable; indeed, it is objecting to them that is often seen as dyspeptic or impolite. It is considered acceptable to assess an author's work not according to the actual arguments and the evidence assembled to support those arguments, but according to the author's imagined political visions or even imagined emotional state. It seems to me that anthropologists - scholars in general, really, but anthropologists in particular - might do well not to reproduce such behavior, but to apply our tools of analysis to understand how this process operates and what its larger political implications might be. 